\title{
Kinga Zawodzińska-Bukowiec, Pseudonim polski. Od czasów najdawniejszych do dziś, Wydawnictwo Libron, Kraków 2014, ss. 327.
}

Pseudonim to subkategoria antroponimiczna, której dotychczas poświęcano mniej uwagi niż imieniu, nazwisku czy przezwisku. Odpowiedzią na to jest praca Kingi Zawodzińskiej-Bukowiec Pseudonim polski. Od czasów najdawniejszych do dziś. I chociaż autorka zaznacza we wstępie, że zarówno językoznawcy, jak i literaturoznawcy zajmowali się pseudonimem (szczególnie literackim), to:

[...] nie wypracowali jak dotąd jednej, spójnej teorii pseudonimu. Dlatego konieczne jest nowe spojrzenie na pseudonim - takie, które pozwoli na uchwycenie nie tylko tych ogólnie znanych wyznaczników pseudonimowości, ale także tych dotąd niedostrzeganych bądź po prostu spychanych na odległy plan rozważań teoretycznych (s. 10).

Badaczka zwraca też uwagę na takie problemy, jak np. nieścisłości definicyjne związane z pojęciem „pseudonim”, trudności z wyznaczeniem cech pseudonimu oraz jego miejsca wśród innych antroponimów, a także konieczność uzupełnienia badań dotyczących historii i rozwoju pseudonimu.

Praca liczy 327 stron i składa się z siedmiu rozdziałów oraz słowniczka terminów, indeksu pseudonimów, a także indeksu antroponimów innych niż pseudonim. We wstępie, będącym pierwszym rozdziałem, oprócz zarysowania problemów badawczych autorka omawia źródła, z których czerpała materiał. Są to m.in.: wykazy i słowniki pseudonimów literackich, Internet, kontakt e-mailowy, publikacje książkowe (np. biografie, literatura faktu), artykuły prasowe, audycje radiowe i telewizyjne, wywiady, teksty reklamowe, 
badania ankietowe. Odwołanie się do licznych źródeł pozwoliło zebrać imponujący materiał badawczy. Metodologię przyjętą w swojej pracy autorka określa jako

[...] wypadkową paradygmatów historyczno-porównawczego, strukturalistycznego oraz paradygmatów opartych na współczesnym spojrzeniu lingwistycznym, ze szczególnym uwzględnieniem kognitywizmu i lingwistyki kulturowej oraz nurtu pragmatyczno-komunikatywnego (s. 16).

Rozdział drugi dotyczy dwóch pojęć związanych z metodologią badań nad pseudonimem, czyli terminów „pseudonimografia” służącego określeniu działu onomastyki, który ,[...] dąży do wypracowania metod i narzędzi badawczych umożliwiających zebranie, deszyfrację pseudonimów, a następnie publikację wyników tych prac w formie słownikowej” (s. 25) - i „pseudonimologia” - która „[...] wykorzystując osiagnięcia pseudonimografii, skupia się na analityczno-syntetycznym opracowaniu zjawiska pseudonimowości oraz jego społecznego, historycznego i językowego funkcjonowania" (s. 25). Autorka docenia osiągnięcia polskiej pseudonimografii, ale zwraca uwagę na zaniedbania w dziedzinie pseudonimologii, o której na gruncie polskim możemy mówić dopiero od drugiej połowy XIX wieku; dodatkowo badania te obejmują prawie wyłącznie pseudonim literacki i konspiracyjny.

$\mathrm{W}$ rozdziale trzecim przedstawiono rozwój pseudonimu na przestrzeni dziejów. Pierwsze pseudonimy pojawiły się już w starożytności. W polszczyźnie natomiast śladów pseudonimowości można doszukiwać się wśród dezinformujących imion apotropeicznych, czyli odpędzających złe moce (Beznos, Matol), które badaczka nazywa „mentalnymi pseudonimami” - jest to nowatorskie i bardzo cenne spojrzenie na genezę pseudonimu. Autorka szczegółowo przedstawia proces rozwoju polskiego pseudonimu, kształtowania się kolejnych jego typów i odmian: „Trwająca kilka wieków ewolucja pseudonimu doprowadziła nie tylko do ogromnej różnorodności formalno-strukturalnej, ale również do bogactwa typologicznego jego form" (s. 163). Rozwój ukazuje na tle historycznym w powiązaniu z sytuacją społeczna, polityczną i religijna, podkreśla także wpływ prądów artystycznych i myślowych. Zwraca uwagę na zależności między rozwojem pseudonimów i innych subkategorii antroponimicznych. 
W rozdziale czwartym, zatytułowanym Teoria pseudonimu, autorka omawia problemy terminologiczne i definicyjne - m.in. różnicę między pseudonimem a anonimem; stara się też uporządkować terminologię (typ a odmiana, rodzaj i gatunek pseudonimu). Przedstawia subkategorialne cechy pseudonimu i rozpatruje tę subkategorię w opozycji do przezwisk i przydomków, z którymi pseudonim często jest mylony. Wylicza funkcje pseudonimów: indentyfikacyjną (adresatywną), dezinformacyjną, a także dodatkowe, fakultatywne funkcje, m.in.: informatywna, praktyczna, ludyczną, ekspresywna, estetyczna, marketingową. Badaczka porusza ponadto zagadnienie „psychologii pseudonimu” - omawia cel, przyczyny zjawiska pseudonimowości, motywy, motywację. W rozdziale tym znajdujemy też informację o sposobach funkcjonowania pseudonimu (pseudonim indywidualny, pseudonimy zespołowe, mikrostruktura nazewnicza, kolektywonimy, socjonimy), a także omówienie kwestii zmiany, „drugiego życia” i statusu prawnego pseudonimu.

Rozdział piąty, jak zapowiada autorka, ,[...] będzie traktował o sposobach nominacji, procesach językowych [...], w których wyniku te formy powstały, oraz o strukturze pseudonimów. Spróbuję również ustalić, czy istnieją strukturalne wyznaczniki subkategorii pseudonimu, a jeśli tak, to jakie" (s. 217). Wśród sposobów nominacji wyróżnia: nominację przez wybór nazwy $\mathrm{z}$ istniejącego zbioru onimów, nominację przez kreację - korzystanie ze zbioru apelatywów, a także kreację nazw sztucznych - ,[...] tworzenie nazw zgodnie z przyjętym kluczem literowym, sylabowym, graficznym [...]" (s. 228). Pod względem strukturalnym pseudonimy dzielą się na fiktonimy, kryptonimy i grafonimy.

„Celem nadrzędnym finalnego rozdziału pracy jest próba całościowego spojrzenia na zjawisko polskiego pseudonimu” (s. 245) - można przeczytać na początku rozdziału szóstego. Badaczka wykorzystuje ustalenia $\mathrm{z}$ poprzednich rozdziałów oraz deklaruje zastosowanie ,$[\ldots]$ metod właściwych zarówno strukturalistycznemu nurtowi badań lingwistycznych, jak i tych charakterystycznych dla szeroko rozumianego nurtu kognitywnego [...]”" (s. 246), aby wypracować właściwą definicję terminu ,pseudonim” i typologię pseudonimów. Za nadrzędne kryterium uznała nosiciela i wyróżniła następujące typy: pseudonim literacki, artystyczny, konspiracyjny, sportowy, przestępczy, 
handlowo-usługowy, prostytucyjny, katowski - prawie wszystkie mają także odmiany.

Ponadto autorka wyszczególniła konstytutywne cechy pseudonimu - po pierwsze definicyjne, czyli takie, które występują w każdym z typów:

1) wtórność i zastępczość wobec antroponimu właściwego; 2) fakultatywność; 3) [...] całkowite lub częściowe ukrycie właściwej nazwy osobowej nosiciela (konspiracja) [...]; 4) skorelowanie funkcji nomen proprium z funkcją dezinformacyjna, skutkujące dwiema płaszczyznami aktywności: oficjalną, czyli nieutajniona, oraz tajną, zakonspirowana; 5) powstawanie w jednorazowym akcie świadomej kreacji lub świadomego wyboru; twórca pseudonimu jest najczęściej sam nosiciel, a jeśli jest to osoba trzecia, to warunkiem zaistnienia pseudonimu jest przyjęcie nazwy przez nosiciela i akceptacja środowiska dla onimicznego statusu pseudonimów (s. 277).

Pseudonimy charakteryzują się też cechami dyferencyjnymi i neutralnymi. Badaczka zaznacza, że granice subkategorii pseudonimu są nieostre, zaś najsilniej reprezentują ją pseudonim literacki i konspiracyjny.

$\mathrm{Z}$ całą pewnością można powiedzieć, że autorka osiagnęła cele, które sobie wyznaczyła: „1) ustalenie miejsca, jakie pseudonim zajmuje w polskim systemie antroponimicznym; 2) uregulowanie niejasności terminologicznych; 3) wyznaczenie [...] zestawu subkategorialnych cech pseudonimu; 4) wytyczenie typologicznej linii rozwojowej polskiego pseudonimu [...]" (s. 285). Praca ta jest ważnym krokiem w badaniach nad polskim pseudonimem (jeśli nie najważniejszą z dotychczas powstałych), ale nie tylko - uporządkowanie pewnych kwestii terminologicznych może być pomocne w badaniach nad innymi kategoriami onimicznymi, zaś sumienność autorki i konsekwentne stosowanie przyjętej metodologii powinny być wzorem dla innych, szczególnie młodych, badaczy języka. 


\section{O Autorce:}

Zuzanna Wośko - doktorantka w Katedrze Języka

Polskiego Katolickiego Uniwersytetu Lubelskiego

Jana Pawła II;

obszar badań: nazwiska od przezwisk dwuczłonowych;

zainteresowania: onomastyka, szczególnie antroponimia i nazewnictwo miejskie, języki słowiańskie.

E-mail: zuzannawosko@gmail.com 